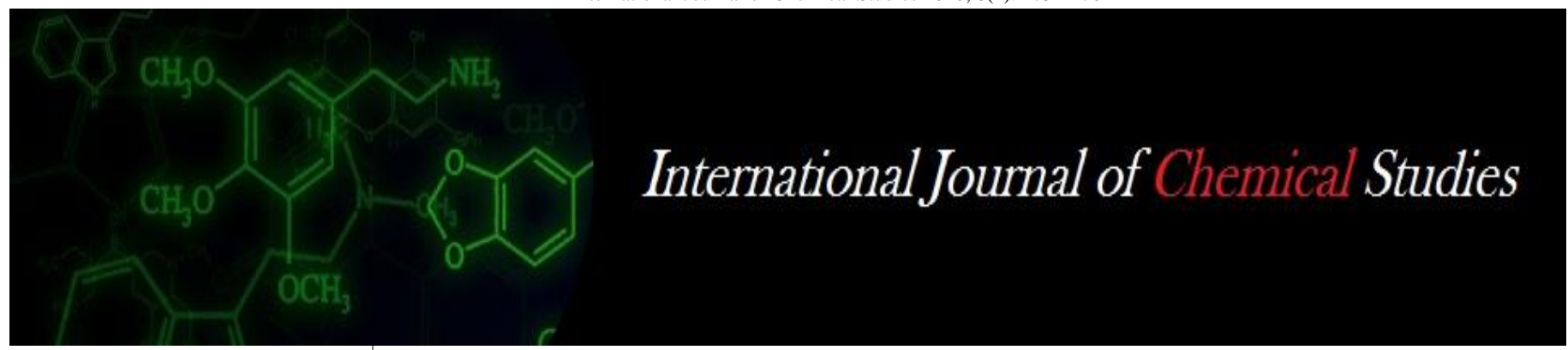

P-ISSN: 2349-8528

E-ISSN: 2321-4902

www.chemijournal.com

IJCS 2020; 8(4): 1754-1761

(C) 2020 IJCS

Received: 07-05-2020

Accepted: 09-06-2020

\section{S Vanisri}

Institute of Biotechnology,

Professor Jayashankar

Telangana State Agricultura

University, Rajendranagar,

Hyderabad, Telangana, India

Charles Wesly K

Institute of Biotechnology,

Professor Jayashankar

Telangana State Agricultural

University, Rajendranagar,

Hyderabad, Telangana, India

Priyanka B

Institute of Biotechnology,

Professor Jayashankar

Telangana State Agricultural

University, Rajendranagar,

Hyderabad, Telangana, India

Sreedhar M

MFPI-Quality Control Lab,

Professor Jayashankar

Telangana State Agricultural

University, Rajendranagar,

Hyderabad, Telangana, India

Ishwrya Laxmi

Department of Genetics and

Plant Breeding, College of

Agriculture, PJTSAU,

Rajendranagar, Hyderabad,

Telangana, India

\section{Srikant Rahul}

Department of Genetics and

Plant Breeding, College of

Agriculture, PJTSAU,

Rajendranagar, Hyderabad,

Telangana, India
Corresponding Author:

S Vanisri

Institute of Biotechnology,

Professor Jayashankar

Telangana State Agricultural

University, Rajendranagar,

Hyderabad, Telangana, India

\section{Mahalanobis $\mathrm{D}^{2}$ and principle component based genetic divergence, selection criteria and genetic variability studies in cold tolerant rice (Oryza sativa) genotypes}

\author{
S Vanisri, Charles Wesly K, Priyanka B, Sreedhar M, Ishwrya Laxmi, \\ and V Srikant Rahul
}

DOI: https://doi.org/10.22271/chemi.2020.v8.i4r.9862

\begin{abstract}
The present investigation was carried to assess the genetic variability, trait relationship, path analysis, $\mathrm{D}^{2}$ analysis and principal component analysis in thirty eight genotypes. All the traits under this study shown the significant difference for ANOVA and high GCV and PCV is observed for Panicle exertion and seed yield per plant. High heritability coupled with high genetic advance as per cent mean was observed for seed yield per plant and tillers per plant. All the characters except test weight showed the positive and significant correlation with seed yield at phenotypic level. Path analysis revealed that filled grains per panicle and spikelet fertility showed positive direct effect on seed yield. Diversity studies indicated that inter cluster distance was maximum between cluster II and VII followed by cluster II and VI \& cluster I and VII. Principle component analysis indicated that first five principal components contributed to $85.81 \%$ of the total diversity is contributed by plant height, seed yield per plant, spikelet fertility, panicle exertion, panicle length, filled grains per panicle and tillers per plant. Selection based on the results of the present study could be exploited in designing future plant breeding programmes for development of high yielding cold tolerant rice varieties.
\end{abstract}

Keywords: PCA, heatmap, genetic diversity, eigen values, rice, variability, correlation

\section{Introduction}

Rice (Oryza sativa L.) is one of the most important staple foods that consumed around the world and in India it is staple food for more than $60 \%$ of population. It accounts for about $43 \%$ of total food grain production and $46 \%$ of total cereal production in the country. Among rice growing countries, India has largest area under rice cultivation in the world i.e., 43.86 million hectares and ranks second in the production with 99.24 million tonnes and the productivity of $2.49 \mathrm{t} / \mathrm{ha}$ next to wheat. (Ministry of Agriculture, Government of India, 2018-19). Shifts in growing season are a major concern in the recent past due to global climate change. Changes in yield performance and the associated traits under different growing seasons are to be studied in the present scenario and breeding programmes needs to be initiated in that direction to develop high yielding, adaptable varieties. Assessment of genetic variability is essential for the successful yield improvement through breeding. Further seed yield depends on various component characters and knowledge of correlation with yield and among yield component traits in addition to identification of the direct and indirect effects of the traits on yield would help in effective yield improvement. Genetic diversity among genotypes which offers better scope for selection in cross combinations involving divergent parents provide an opportunity for bringing together gene constellations of diverse nature and also promising segregant derivatives which result due to complementary interaction of divergent genes in parents are expected. (Murthy and Arunachalam, 1996 and Rahman, et al., 1997) [17, 18]. Principal component analysis is an adaptive data analysis technique which is effectively used to visualize the similarity and difference between the genotypes and helps in identifying the quantitative characters contributing maximum towards genetic divergence (Jindal et al., 2018). The present investigation was undertaken in the above context to obtain promising rice genotypes for further breeding programme. 


\section{Materials and Methods}

Thirty eight rice genotypes were evaluated in RBD during mid Kharif, 2018 (Nursery sowings were done on $5^{\text {th }}$ July, 2018) at College Farm, Professor Jayashankar Telangana State Agricultural University, Rajendranagar, Hyderabad. Observations were recorded on five randomly selected plants in each replication for traits days to $50 \%$ flowering, plant height $(\mathrm{cm})$, tillers per plant, panicle length $(\mathrm{cm})$, panicle exertion, spikelet fertility $(\%)$, test weight (gm) and seed yield per plant $(\mathrm{gm})$. As stated to the formula given by Allard (1960) ${ }^{[1]}$, broad sense Heritability $\left(h^{2}\right)$ was calculated. The genetic advance as per cent mean was calculated according to Burton (1952) ${ }^{[5]}$. Genotypic and phenotypic correlation coefficients and path coefficient analysis as per Dewey and Lu (1959) ${ }^{[8]}$, GCV, PCV as per Falconer (1981), D² analysis as per Mahalanobis (1936) through INDOSTAT software and Principal component analysis using XLSTAT software to reveal best relationship among traits.

\section{Results and Discussion}

Analysis of variance showed the significant difference for all the characters studied indicates that there is ample scope for selection. The trait tillers per plant varied from 7.20 (SKAU$341)$ to 18.05 (SKAU-382). With respect to panicle length, the longest panicle was 27.10 (VIVEK DHAN-82), while the shortest one is 14.75 (HPR-2373). The mean value for filled grains per panicle is 94.51 with a range of 40.3 (K-429) to 165.4 (VIVEK DHAN-62), while seed yield per plant ranged from 5.68 (HIMALAYA-1) to 29.08 (HIMALAYA-2216).

The genetic variability is depicted in the form of box plots (Table 1, Fig. 2) showed the frequency distribution for nine quantitative traits among thirty eight genotypes. High PCV and GCV was observed for characters panicle exertion (33.84, $25.56)$ followed by seed yield per plant $(28.95,28.18)$, filled grains per panicle $(26.05,22.60)$ and tillers per plant $(23.87$, 23.56). While moderate values recorded for plant height and low values for spikelet fertility. Similar results were obtained by Kahani et al. (2015) [12], Das (2015) [7], Gautama et al., (2016) ${ }^{[9]}$ and Shet et al., (2017) ${ }^{[22]}$. Quantile-Quantile plots (Fig. 3) showed normal distribution for all the traits except tillers per plant, filled grains per panicle and seed yield per plant which skewed towards the positive side. Hence selecting the genotypes which emerged as outliners in box plots and which skewed towards the positive side in Q-Q plots would be beneficial. High heritability coupled with high genetic advance as per cent mean was observed for seed yield per plant $(95,56.52)$ followed by tillers per plant $(97,47.90)$ and filled grains per panicle $(75,40.41)$. The results were in concordance with Rajput et al., (2013), Shrivastava et al., (2014) ${ }^{[23]}$, Arvind et al., (2015) and Chandra et al., (2017) ${ }^{[6]}$. Depicted in Histogram (Fig. 1).

Traits relationship for yield and yield component characters were studied in the present investigation and the results are presented in (Table 2) and depicted in Correlogram (Fig. 4) revealed that the seed yield correlated significantly positive with filled grains per panicle, spikelet fertility, plant height, days to $50 \%$ flowering, tillers per plant, panicle exertion and panicle length indicating that these characters could be considered as a criteria of selection for higher yield, as there were mutually and directly associated with seed yield. Similar results were obtained by Guru et al. (2016) ${ }^{[10]}$, Shakhwat et al. (2017) ${ }^{[20,21]}$, Sowmiya et al. (2017) and Kalyan et al. (2017) ${ }^{[13]}$. While, a negative significant association of seed yield was shown by 1000 seed weight $(-0.0151)$.
Direct and Indirect effects revealed (Table 3, Fig. 6) that the trait filled grains per panicle exerting the highest direct positive effect on seed yield per plant followed by plant height, tillers per plant and days to $50 \%$ flowering at the phenotypic level. The results are in concordance with earlier reports of Guru et al., (2012), Seyoum et al., (2012), Manikyaminnie et al., (2013) ${ }^{[15]}$ and Biswajit et al., (2017) [3]. The positive direct effects of the remaining traits were low to be considered of any consequence. On the other hand, the negative direct effect on seed yield was recorded by panicle length. The high positive indirect effect on seed yield per plant was panicle length via plant height and spikelet fertility via plant height. Hence, these traits should be considered as important for selection in yield improvement.

Heat map (Fig. 5) depicted that filled grains per panicle exhibiting greater variation among the genotypes followed by plant height and spikelet fertility. The yellow and blue colour corresponds high and low diversity for expressed traits, respectively, while green representing median levels of expression. Thirty eight genotypes were grouped into seven clusters based on euclidean distances using Tocher's method in $\mathrm{D}^{2}$ analysis. The distribution of genotypes into various clusters is displayed (Table 4). Among all 7 clusters, cluster I was the largest comprising about 13 genotypes followed by the cluster III (9 genotypes), cluster IV (6 genotypes) and remaining clusters II, V, VI and VII are monoclusters. The average Intracluster values (Table 5, Fig. 7) ranged from 0.00 to 108.00. While intercluster distances were maximum between cluster II \& VII (668.03), followed by cluster I \& VII (529.37) and cluster II \& VI (503.96). Minimum intercluster distances were observed between cluster VI \& VII (136.50) and cluster I \& II (141.56). The relative contribution (Table 6) of plant height to the total diversity was the highest $(34.28 \%$ ) followed by seed yield per plant $(27.14 \%$ ) and days to $50 \%$ flowering $(15.07 \%)$, while lowest contribution is from test weight $(4.21 \%)$ followed by panicle length $(2.42 \%)$. The characters filled grains per panicle, plant height, seed yield per plant and days to flowering contributed $76.47 \%$ towards total divergence.

PCA is the eigenvector-based multivariate analyses that best explains the variance in the data.

The five most informative principal components in the study explained $85.81 \%$ of the variation, with eigen-values of 3.42 , $1.46,1.19,0.98$ and 0.64 of variations among the traits respectively (Table 7). Similar results were reported by Mahendran et al. (2015) ${ }^{[14]}$. PC1 accounted for highest variability and highly contributed by plant height, seed yield per plant, spikelet fertility, panicle exertion, panicle length, filled grains per panicle and tillers per plant in positive direction. In second principal component has highest contribution of days to $50 \%$ flowering. PC3, PC4 were related to test weight and tillers per plant respectively. Scree plot (Fig. 8) explained the gradual decline of eigen values from PC1 to PC5. Selection of characters for seed yield per plant via days to $50 \%$ flowering, spikelet fertility and filled grains per panicle would be beneficial. The first two principal components biplot including loadings of the various characters along with the genotypes spread over is given in Fig. 9. The ordination of the rice germplasm revealed that accessions VL DHAN-206, VL DHAN-209, VL DHAN-208, VL DHAN-65, VL DHAN-207, VIVEK DHAN-62, VIVEK DHAN-82, RP-2421 and SUKARA DHAN-1 were distinct for the characters studied. Variables Days to $50 \%$ flowering, filled grains per panicle and seed yield per plant showed highest variation can be seen on the right and left hand 
quadrant of the plot. The variables that are on same quarter are very close to each other signify that there are positive correlations between them and results are similar with earlier statistical approaches in this paper. The genotypes and the traits lying in the same quarter representing the possibility of selection of genotypes for the specific traits. Thus, the biplot diagrams can be used to select genotypes that might have favourable combinations of traits for use in a breeding projects.

Table 1: Estimates of range, variability, heritability, genetic advance for Seed yield and its components in rice germplasm lines

\begin{tabular}{|c|c|c|c|c|c|c|c|}
\hline \multirow[b]{2}{*}{ Characters } & \multirow{2}{*}{ mean } & \multicolumn{2}{|c|}{ Range } & \multicolumn{2}{|c|}{ Coefficient of variation } & \multirow{2}{*}{$\begin{array}{c}\text { Heritability in broad } \\
\text { sence } h^{2} \text { bs }(\%)\end{array}$} & \multirow{2}{*}{$\begin{array}{c}\text { Gen adv. As per cent of } \\
\text { mean (at } 5 \% \text { level) }\end{array}$} \\
\hline & & Min & $\operatorname{Max}$ & phenotypic & genotypic & & \\
\hline Plant height $(\mathrm{cm})$ & 119.6 & 76.1 & 151.8 & 18.00 & 17.86 & 98.00 & 36.51 \\
\hline Days to $50 \%$ flowering & 84 & 71 & 102 & 10.14 & 9.98 & 97.00 & 20.25 \\
\hline Tillers/ plant & 11 & 7 & 18 & 23.87 & 23.56 & 97.00 & 47.90 \\
\hline Panicle Exertion & 3.35 & 1.5 & 5.5 & 33.84 & 25.56 & 57.00 & 39.77 \\
\hline Panicle length & 22.74 & 14.75 & 27.1 & 12.31 & 11.95 & 94.00 & 23.90 \\
\hline Spikelet Fertility & 86 & 73 & 97 & 7.61 & 5.62 & 55.00 & 8.55 \\
\hline Filled Grains/ Panicle & 94.51 & 40.3 & 165.4 & 26.05 & 22.60 & 75.00 & 40.41 \\
\hline Test Weight & 23.12 & 19.35 & 27.19 & 10.08 & 7.89 & 61.00 & 12.73 \\
\hline Seed Yield/ Plant & 18.80 & 5.68 & 29.08 & 28.95 & 28.18 & 95.00 & 56.52 \\
\hline
\end{tabular}

Table 2: Phenotypic correlation coefficient analysis of yield and yield contributing characters in rice

\begin{tabular}{|c|c|c|c|c|c|c|c|c|c|}
\hline Character & $\begin{array}{c}\text { Plant } \\
\text { height }(\mathbf{c m})\end{array}$ & $\begin{array}{c}\text { Days to } \\
50 \% \text { flowering }\end{array}$ & $\begin{array}{c}\text { Tillers/ } \\
\text { Plant }\end{array}$ & \begin{tabular}{|c|} 
Panicle \\
Exertion
\end{tabular} & $\begin{array}{l}\text { Panicle } \\
\text { Length }\end{array}$ & $\begin{array}{l}\text { Spikelet } \\
\text { Fertility }\end{array}$ & \begin{tabular}{c|} 
Filled \\
grains/panicle
\end{tabular} & $\begin{array}{c}\text { Test } \\
\text { weight }\end{array}$ & $\begin{array}{c}\text { Seed yield } \\
\text { /plant }\end{array}$ \\
\hline Plant height $(\mathrm{cm})$ & 1.0000 & $0.2296 *$ & 0.1526 & $0.3657 * *$ & $0.7308 * *$ & $0.4065 * *$ & $0.2990 * *$ & -0.1126 & $0.4681 * *$ \\
\hline Days to $50 \%$ flowering & & 1.0000 & 0.0627 & -0.1170 & 0.0717 & 0.0348 & $0.3353 * *$ & $-0.3772 * *$ & $0.3053 * *$ \\
\hline Tillers/ Plant & & & 1.0000 & $0.2601 *$ & 0.2115 & 0.2031 & 0.0713 & -0.1740 & $0.3308 * *$ \\
\hline Panicle Exertion & & & & 1.0000 & $0.3716 * *$ & $0.3858 * *$ & $0.3074 * *$ & 0.0452 & $0.3478 * *$ \\
\hline Panicle Length & & & & & 1.0000 & $0.2919 *$ & 0.1364 & -0.0973 & $0.3245^{* *}$ \\
\hline Spikelet Fertility & & & & & & 1.0000 & $0.4166^{* *}$ & 0.0609 & $0.4367 * *$ \\
\hline Filled rains/panicle & & & & & & & 1.0000 & -0.0120 & $0.5020 * *$ \\
\hline Test weight & & & & & & & & 1.0000 & -0.0151 \\
\hline Seed yield /plant & & & & & & & & & 1.0000 \\
\hline
\end{tabular}

Table 3: Phenotypic Path coefficient analysis of yield and yield contributing characters in rice

\begin{tabular}{|c|c|c|c|c|c|c|c|c|c|}
\hline Character & $\begin{array}{c}\text { Plant } \\
\text { height }(\mathbf{c m})\end{array}$ & $\begin{array}{c}\text { Days to } \\
\text { 50\% flowering }\end{array}$ & $\begin{array}{c}\text { Tillers/ } \\
\text { Plant }\end{array}$ & $\begin{array}{c}\text { Panicle } \\
\text { Exertion }\end{array}$ & $\begin{array}{c}\text { Panicle } \\
\text { Length }\end{array}$ & $\begin{array}{c}\text { Spikelet } \\
\text { Fertility }\end{array}$ & $\begin{array}{c}\text { Filled grains/ } \\
\text { panicle }\end{array}$ & $\begin{array}{c}\text { Test } \\
\text { weight }\end{array}$ & $\begin{array}{c}\text { Seed yield } \\
\text { /plant }\end{array}$ \\
\hline Plant height $(\mathrm{cm})$ & 0.2493 & 0.0572 & 0.0325 & 0.0912 & 0.1821 & 0.1046 & 0.0745 & -0.0281 & 0.4681 \\
\hline Days to 50\% flowering & 0.0454 & 0.1980 & 0.0100 & -0.0232 & 0.0142 & 0.0081 & 0.0664 & -0.0747 & 0.3053 \\
\hline Tillers/ Plant & 0.0320 & 0.0124 & 0.2458 & 0.0627 & 0.0453 & 0.0519 & 0.0179 & -0.0452 & 0.3308 \\
\hline Panicle Exertion & 0.0310 & -0.0099 & 0.0216 & 0.0847 & 0.0315 & 0.0330 & 0.0261 & 0.0038 & 0.3478 \\
\hline Panicle Length & -0.0076 & -0.0007 & -0.0019 & -0.0039 & -0.0104 & -0.0315 & -0.0014 & 0.0010 & 0.3245 \\
\hline Spikelet Fertility & 0.0516 & 0.0050 & 0.0260 & 0.0479 & 0.0371 & 0.1231 & 0.0513 & 0.0071 & 0.4367 \\
\hline Filled grains/panicle & 0.0803 & 0.0901 & 0.0196 & 0.0826 & 0.0367 & 0.1120 & 0.2688 & -0.0032 & 0.5020 \\
\hline Test weight & -0.0140 & -0.0468 & -0.0228 & 0.0056 & -0.0121 & 0.0072 & -0.0015 & 0.1241 & -0.0151 \\
\hline
\end{tabular}

(Residual effect 0.7271)

Table 4: Distribution of 38 Genotypes into Clusters

\begin{tabular}{|c|c|c|}
\hline Clusters No. of Entries & Genotypes \\
\hline I & 19 & $\begin{array}{r}\text { SHALIMAR-1, SKAU-389, SKAU-339, CHINA-1007, V L DHAN-86, HPR-2143, SKAU-5, HPR-2513, } \\
\text { SKAU-341, HPR-2336, CHINA-988, RP-2421, JHELUM, VIVEK DHAN-82, VIVEK DHAN-65, V L } \\
\text { DHAN-221, SUKARADHAN-1, CHENAB, CHINA-1039 }\end{array}$ \\
\hline II & 1 & HIMALAYA-2216 \\
\hline III & 9 & K-475, K-332, K-429, K-116, HPR-1068, HIMALAYA-741, MTU 1010, HIMALAYA-1, TELLAHAMSA \\
\hline IV & 6 & V L DHAN-206, V L DHAN-207, V L DHAN-208, V L DHAN-209, VIVEK DHAN-62, SKAU-382 \\
\hline V & 1 & RAJENDRA \\
\hline VI & 1 & VIVEK DHAN-85 \\
\hline VII & 1 & HPR-2373 \\
\hline
\end{tabular}

Table 5: Intra and Inter cluster average distances $\left(\mathrm{D}^{2}\right)$ for 9 quantitative traits in Rice

\begin{tabular}{|c|c|c|c|c|c|c|c|}
\hline Clusters & Cluster 1 & Cluster 2 & Cluster 3 & Cluster 4 & Cluster 5 & Cluster 6 & Cluster 7 \\
\hline Cluster 1 & 108.00 & 141.56 & 264.54 & 206.92 & 197.07 & 333.74 & 529.37 \\
\hline Cluster 2 & & 0.00 & 487.28 & 153.74 & 291.00 & 503.96 & 668.03 \\
\hline Cluster 3 & & & 100.76 & 354.44 & 186.68 & 173.77 & 293.83 \\
\hline Cluster 4 & & & & 89.22 & 354.30 & 436.68 & 398.47 \\
\hline Cluster 5 & & & & & 0.00 & 150.97 & 385.33 \\
\hline Cluster 6 & & & & & & 0.00 & 136.50 \\
\hline Cluster 7 & & & & & & & 0.00 \\
\hline
\end{tabular}


Table 6: Relative contribution of different characters to genetic diversity

\begin{tabular}{|c|c|c|}
\hline S. No. & Characters & Contribution \% \\
\hline 1 & Plant Height & $34.28 \%$ \\
\hline 2 & Days to Flowering & $15.08 \%$ \\
\hline 3 & Tillers per plant & $11.66 \%$ \\
\hline 4 & Panicle Exertion & $4.11 \%$ \\
\hline 5 & Panicle Length & $2.42 \%$ \\
\hline 6 & Spikelet Fertility & $4.85 \%$ \\
\hline 7 & No. of Filled Grains & $7.97 \%$ \\
\hline 8 & Test Weight & $0.85 \%$ \\
\hline 9 & Seed yield per plant & $27.14 \%$ \\
\hline
\end{tabular}

Table 7: Eigen values, contribution of variability and factor loading for PCA

\begin{tabular}{|c|c|c|c|c|c|}
\hline & P1 & P2 & P3 & P4 & P5 \\
\hline Eigenvalue & 3.425 & 1.465 & 1.199 & 0.988 & 0.646 \\
\hline Variability (\%) & 38.058 & 16.273 & 13.322 & 10.980 & 7.182 \\
\hline Cumulative \% & 38.058 & 54.332 & 67.654 & 78.634 & 85.816 \\
\hline Plant height (cm) & 0.783 & -0.023 & -0.283 & -0.428 & -0.080 \\
\hline Days to 50\% flowering & 0.332 & 0.836 & 0.173 & -0.083 & -0.203 \\
\hline Tillers/ plant & 0.443 & -0.066 & -0.281 & 0.759 & -0.295 \\
\hline Panicle Exertion & 0.683 & -0.348 & -0.124 & 0.196 & 0.424 \\
\hline Panicle length & 0.667 & -0.114 & -0.536 & -0.359 & -0.134 \\
\hline Spikelet Fertility & 0.740 & -0.275 & 0.324 & 0.020 & 0.130 \\
\hline Filled Grains/ Panicle & 0.649 & 0.218 & 0.581 & -0.013 & 0.211 \\
\hline Test Weight & -0.176 & -0.709 & 0.449 & -0.200 & -0.393 \\
\hline Seed Yield/ Plant & 0.772 & 0.026 & 0.250 & 0.177 & -0.313 \\
\hline
\end{tabular}

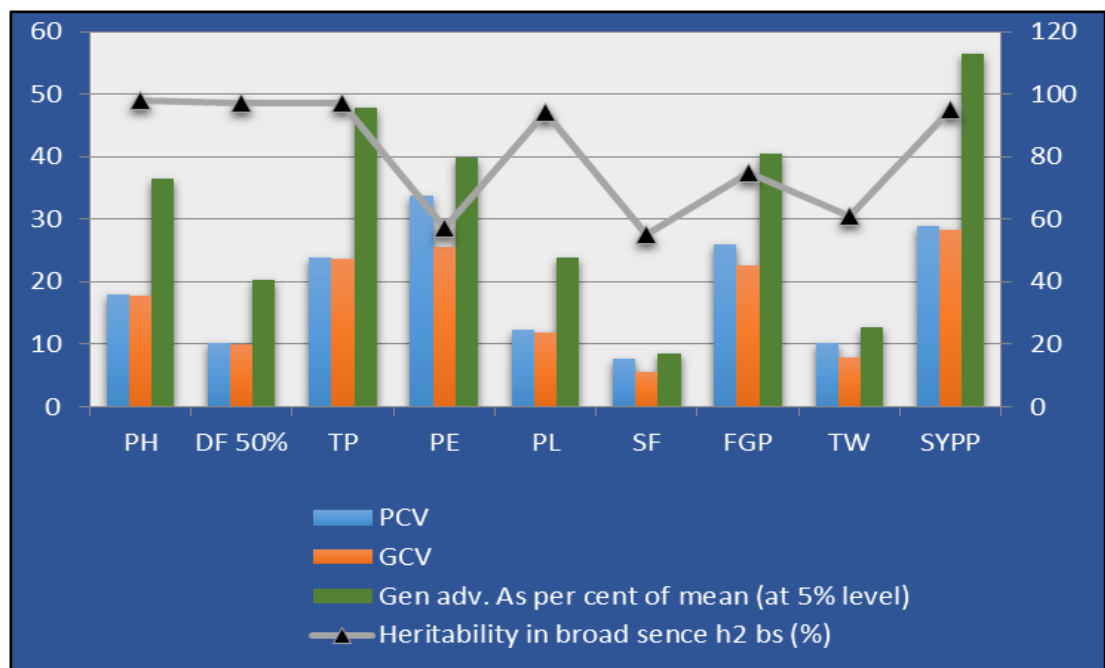

Fig 1: Histogram of heritability in broad sense $\left(h^{2}\right)$, genetic advance, phenotypic and genotypic co-efficient of variation (GCV) for Seed yield and its component characters in rice.

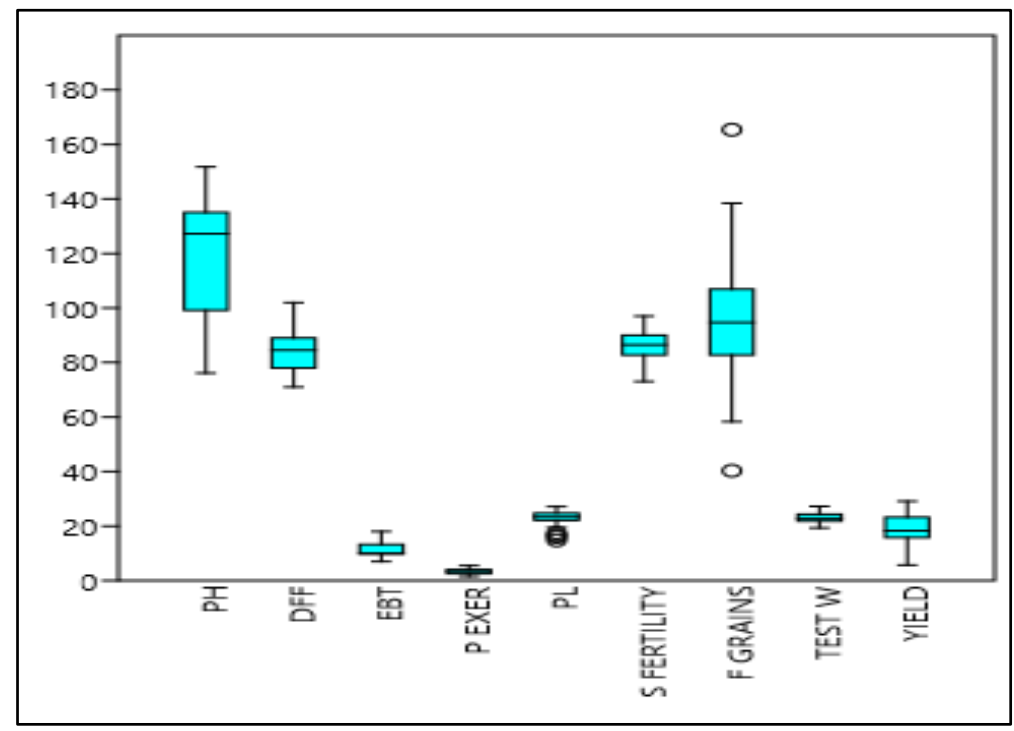

Fig 2: Box-plots showing variation of the data from the 9 quantitative traits evaluated in 38 accessions 


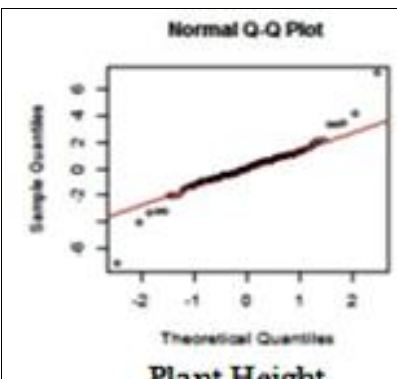

Plant Height

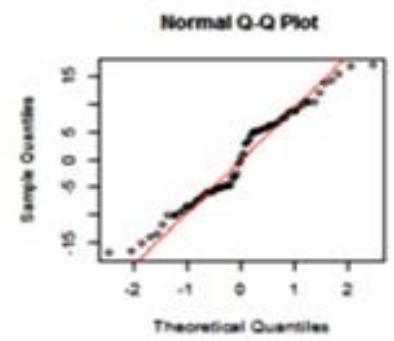

Filled grains per panicle

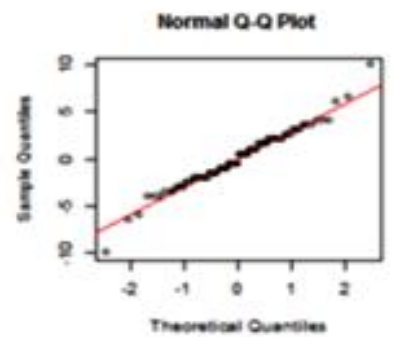

Spikelet fertility

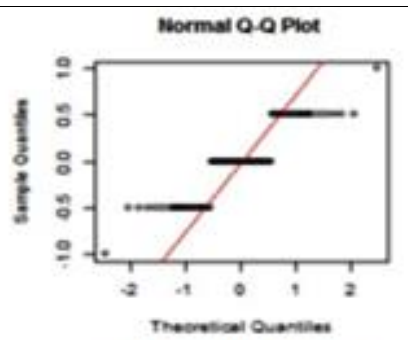

Tillers per plant

Normal o. Plot

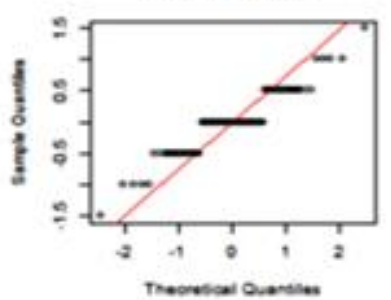

Panicle Exertion

Mormat O. Q Phot

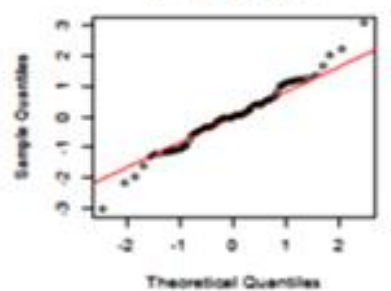

Test weight

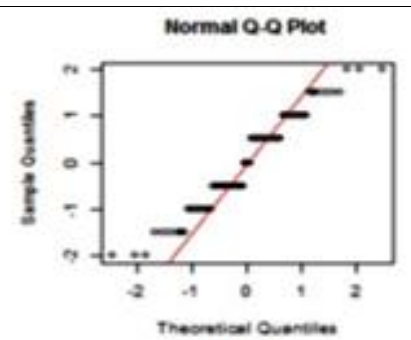

DFF

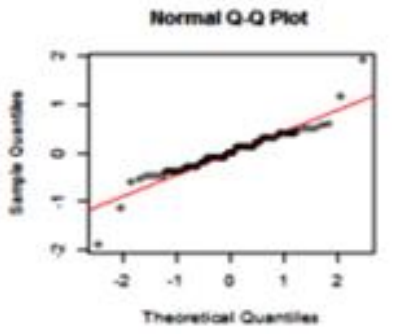

Panicle Length

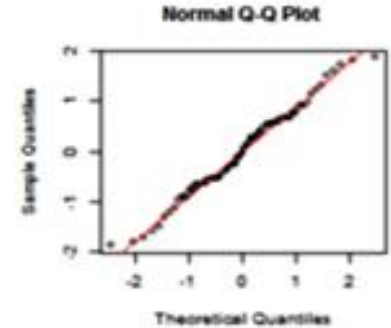

Seed yield per plant

Fig 3: Quantile-Quantile plots showing the distribution for yield and its attributing traits

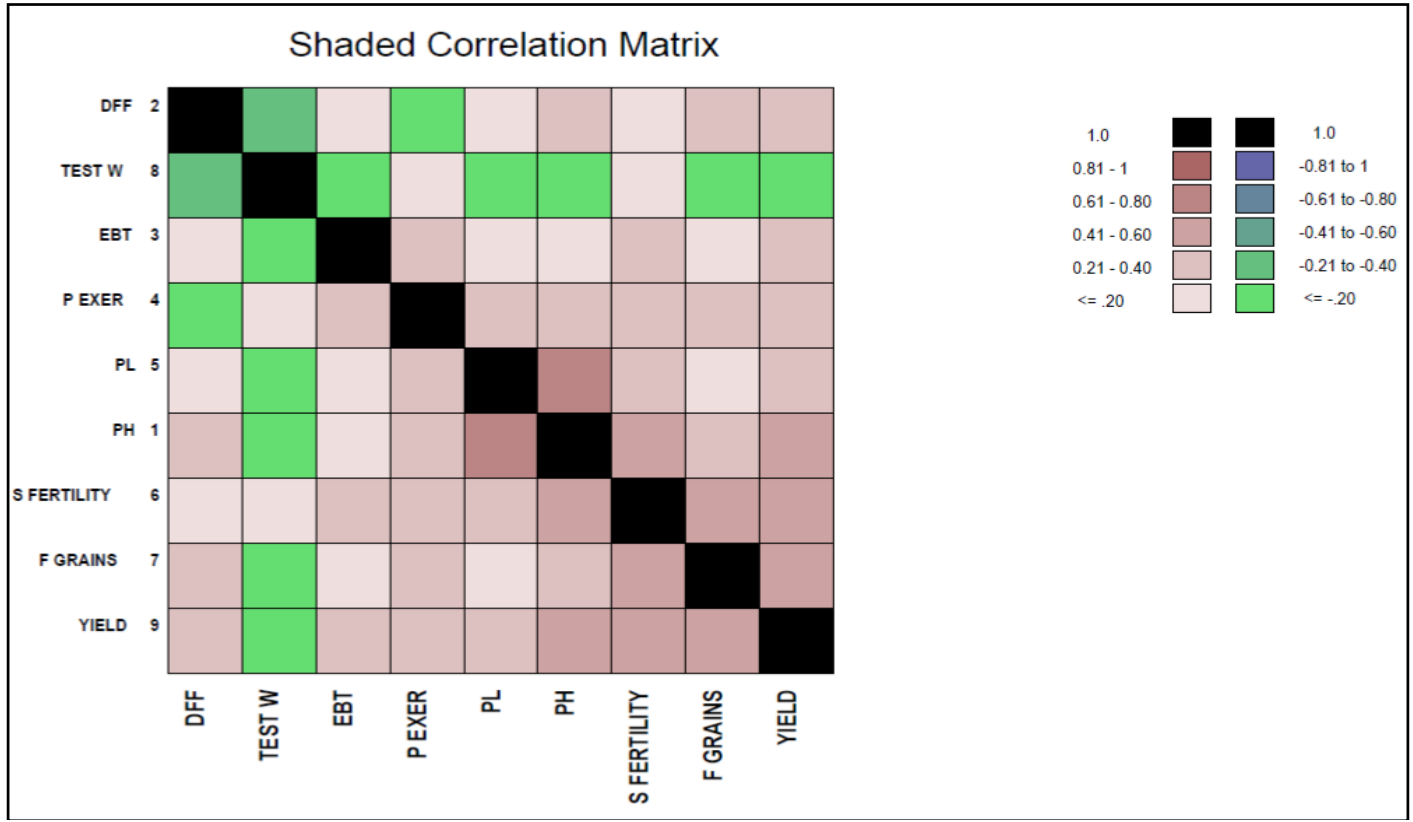

Fig 4: Correlogram visualizing the correlation in yield and its attributing traits 


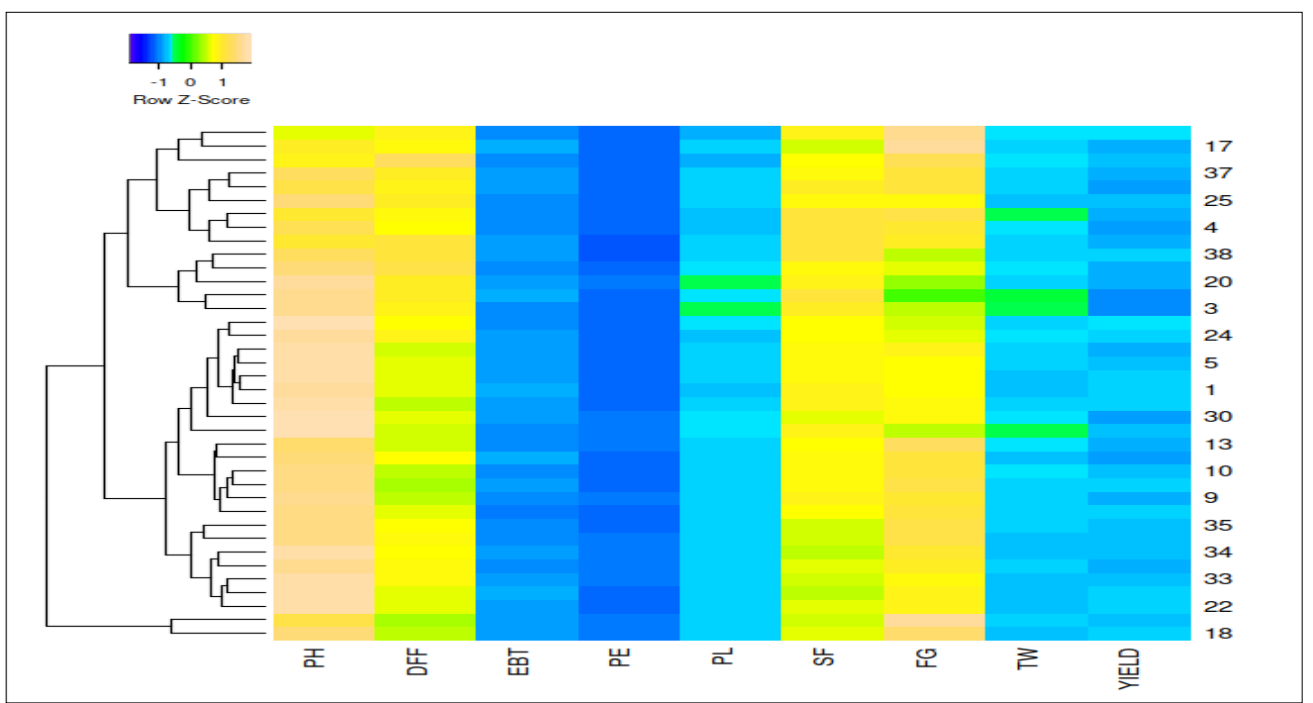

Fig 5: Heatmap depicting the genetic variability in for yield and its attributing traits

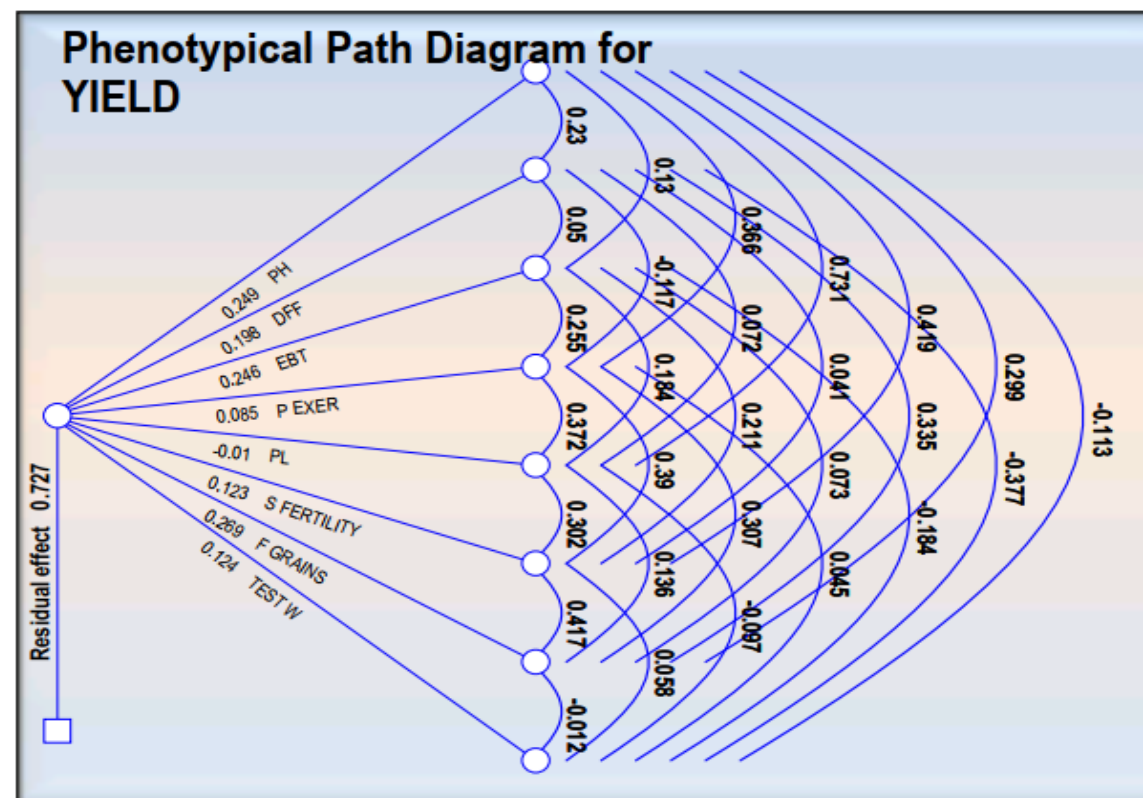

Fig 6: Phenotypical Path diagram for yield

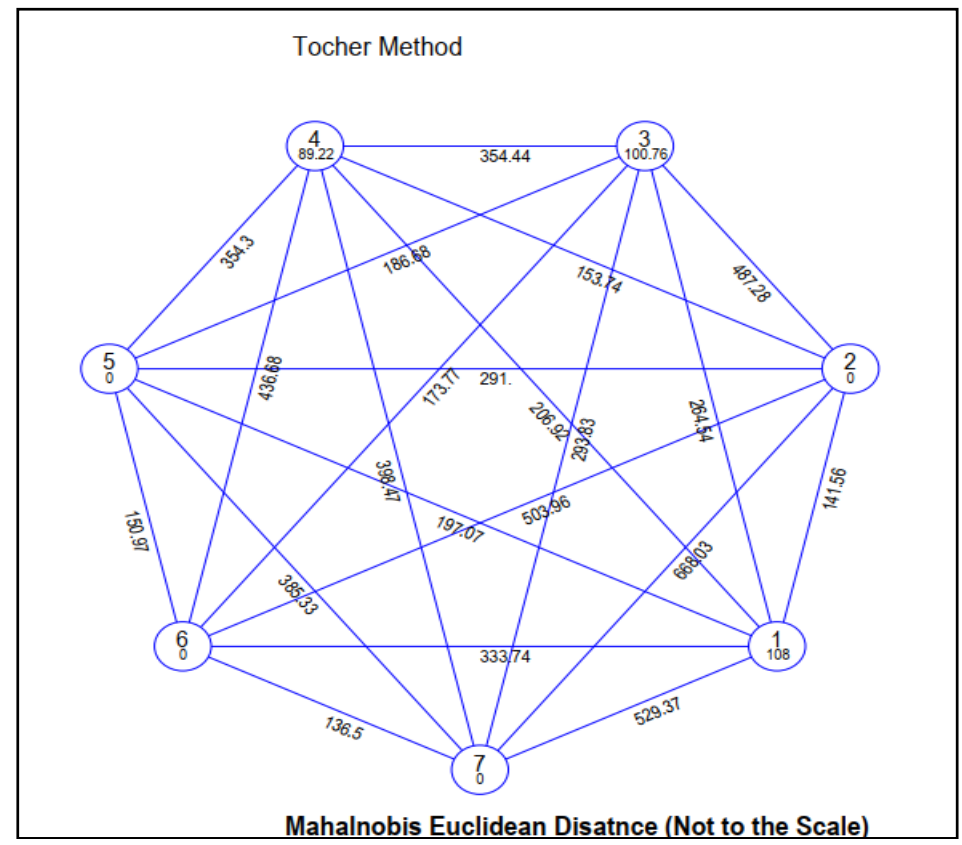

Fig 7: Cluster diagram depicting intra and intercluster distances. (The figure is not exactly to the scale) 


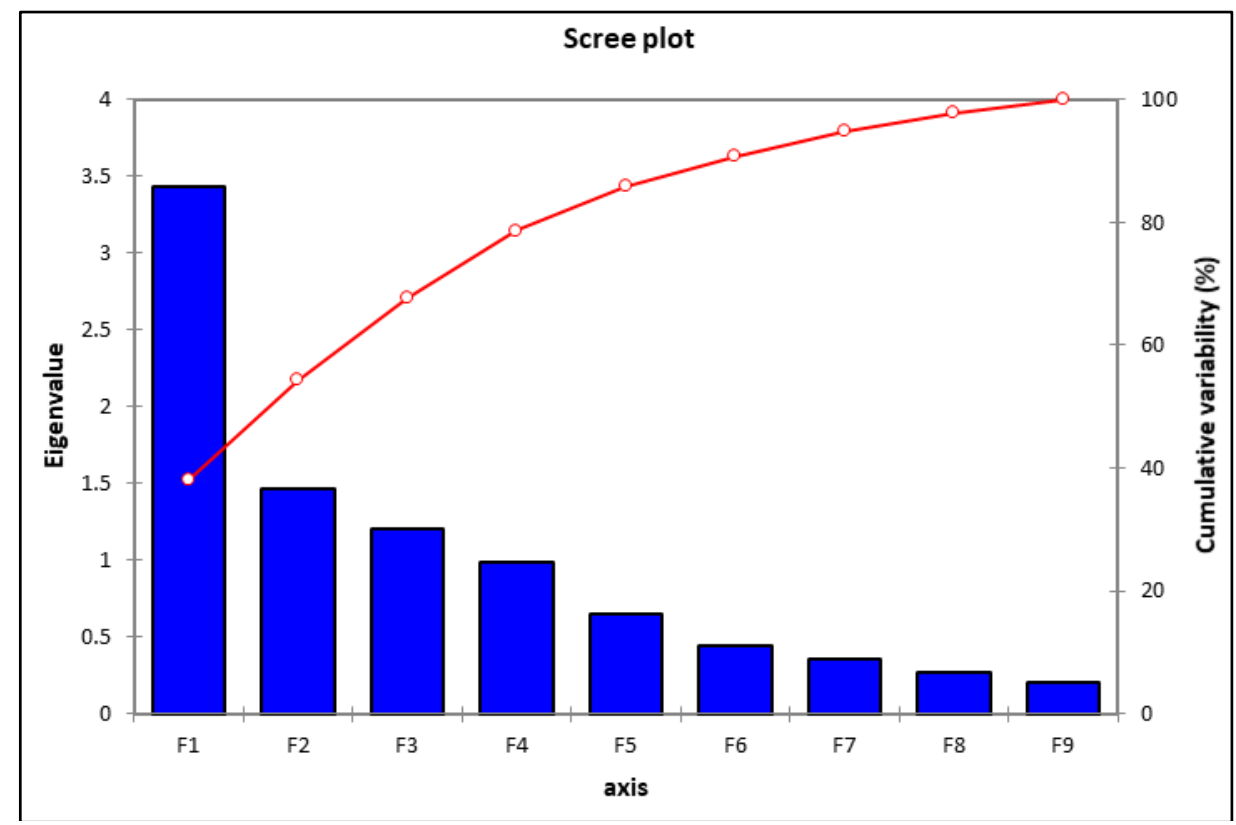

Fig 8: Eigen values of principal components for yield and its attributing traits

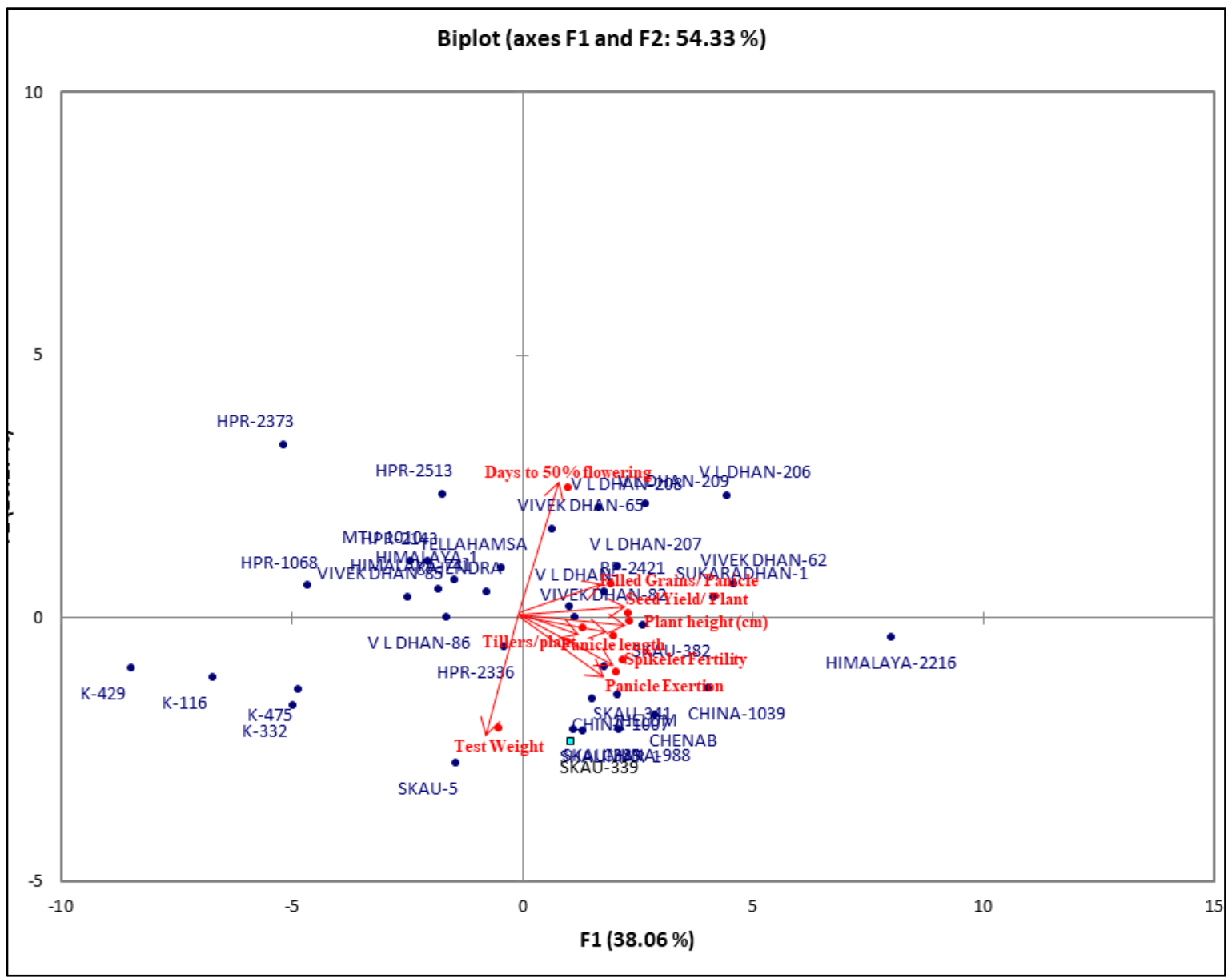

Fig 9: Biplot of Principal component analysis

\section{Conclusion}

The results conclude that significant differences among genotypes for all the characters indicate the presence sufficient variation among the genotypes. High GCV and PCV recorded for the traits seed yield per plant, panicle exertion, filled grains per panicle and tillers per plant, while high heritability coupled with high genetic advance as per cent mean was shown for all characters except panicle exertion, spikelet fertility and test weight. There is positive associations between seed yield per plant and to all characters except test weight. Selection for these traits would be effective to enhance yield potential. The traits filled grains per panicle, tillers per plant showed highest positive direct effects on seed yield. Clusters II \&VII, I \& VII and II \& VI has the highest inter cluster distance and genotypes present in these clusters are more diverse and can be used as parents for further breeding programme to improve yield. PCA studies identified that only few characters play a prominent role in classifying the variation existing in the germplasm. About $85.81 \%$ of the total variability was explained by first five 
principal components. As there is a greater level of variability present among the genotypes and traits towards diversity, there is an ample scope for enhancement of the new varieties with the use of these germplasm in rice breeding programmes.

\section{References}

1. Allard RW. Principles of Plant Breeding. John Willey and Sons Inc., New York, 1960

2. Aravind AJ, Bokosi JM. Evaluation of genetic variability, heritability and genetic advance for yield and yield components in rice genotypes. International Journal of Pure \& Applied Bio Sciences. 2015; 5(4):909-915.

3. Biswajit P, Kaushik RP. Correlation for yield and quality traits in rice (Oryza sativa L.). Journal of Rice Research. 2017; 4(1, 2):1-5.

4. Brejda JJ, Moorman TB, Karlen DL, Dao TH. Identification of regional soil quality factors and indicators. I. Central and Southern High- Plains. Soil Sci. Soc. Am. J. 2000; 64:2115-2124.

5. Burton GW. Quantitative inheritance of grasses. Proc. $6^{\text {th }}$ Int. Grassland congress. 1952; 1:277-283.

6. Chandra B, Satish T, Dayakar Reddy, Sudheer Kumar S. variability parameters for yield, its components and quality traits in rice (Oryza sativa L.). Crop Res. 2017; 38(3):144-146.

7. Das P, Nutan KK, Singla-Pareek SL, Pareek A. Understanding salinity responses and adopting 'omicsbased' approaches to generate salinity tolerant cultivars of rice. Front. Plant Sci. 2015; 6:712

8. Dewey JR, Lu KH. Correlation and path coefficient analysis of components of crested wheat grass seed production. Agronomy Journal. 1959; 51:515-518.

9. Gautama, Sunil Kumar B, Prakash M. Variability studies for some yield and quality traits in rice. (Oryza sativa L.). Plant Archives. 2016; 14(1):535-536.

10. Guru T, Padma V, Reddy DVY, Rao PR, Rao S. Correlation and path coefficient analysis for grain yield and other component traits in rice genotypes. International Journal of Agriculture Sciences and Research. 2016; 6(5):363-370.

11. Jindal Y, Rajesh Yadav, Phogat DS. "Principal component analysis and determination of the selection criteria in fodder cowpea (Vigna unguiculata (L) Walp.) genotypes." Range Management and Agroforestry 39 2018; (2):191-196.

12. Kahani J, Hittalmani S. Genetic Analysis and Traits Association in F2 Intervarietal Populations in Rice Under Aerobic Condition. J Rice Res. 2015; 3:152.

13. Kalyan B, Radha Krishna KV, Rao LVS. Correlatiuon coefficient analysios for yield and its components in rice (Oryza sativa L.) genotypees. International Journal of Current Microbiology and Applied Sciences. 2017; 6(7):2425-2430.

14. Mahendran R, Veerabadhiran P, Robin S, Raveendran M. Principal component analysis of rice germplasm accessions under high temperature stress. Int. J Agric. Sci. Res. 2015; 5:355-360

15. Manikyaminnie C, Dayakarreddy T, SurendraRaju Ch. Correlation and path analysis for yield and its components in rice (Oryza sativa L.). Journal of Research. ANGRAU. 2013; 41(1):132-134.

16. Ministry of Agriculture, Government of India. 2018-19. https:/ /www.indiastat.com/default.aspx.
17. Murthy BR, Arunachalam V. The nature of genetic divergence in relation to breeding system in some crop plants. Indian J Genet. 1996; 26:188-198.

18. Rahman MB, Acharya SN, Sukla, Pande K. Genetic divergence in low land rice genotypes. Oryza. 1997; 34(3):209-212.

19. Seyoum M, Sentayehualamerewandkassahun Bantte, Genetic variability, heritability correlation coefficient and path analysis for yield and yield related traits in upland rice (Oryza sativa L.). Journal of Plant Sciences. 2012; 7(1):13-22.

20. Shakhawat HM, Fakhrul IM, Rehenuma T. Assessment of genetic variability of some exotic hybrid vareties of rice (Oryza sativa L.). Journal of Plant Sciences. 2017; 12(1):22-29.

21. Shakhawat, HM, Fakhrul IM, Rehenuma T. Assessment of genetic variability of some exotic hybrid vareties of rice (Oryza sativa L.). Journal of Plant Sciences. 2017; 12(1):22-29.

22. Shet, Sumit, Chaturvedi, Pyare Lal, Pandey MP, Verma S et al. Component analysis for grain yield in hybrid rice under traits condition. Oryza. 2017; 45(1):1-6.

23. Shrivastava et al. Analysis of variability, correlation and path coefficient in induced mutants of aromatic nonbasmati rice. Tropical Agricultural Research and Extension. 2014; 11(1):731-742. 